PACS: $87.14 . \mathrm{C}++\mathrm{c}$, 87.16.Dg

\title{
NOVEL PHOSPHONIUM DYE TDV1 AS A POTENTIAL FLUORESCENT PROBE TO MONITOR DNA INTERACTIONS WITH LYSOZYME AMYLOID FIBRILS
}

\author{
(D) Olga Zhytniakivska ${ }^{1}$, (D) Uliana Tarabara ${ }^{1 *}$, Kateryna Vus $^{1}$, (D) Valeriya Trusova ${ }^{1}$, \\ (1D)Galyna Gorbenko ${ }^{1}$, N. Gadjev ${ }^{2}$, Todor Deligeorgiev ${ }^{2}$ \\ ${ }^{1}$ Department of Nuclear and Medical Physics, V.N. Karazin Kharkiv National University \\ 4 Svobody Sq., Kharkiv, 61022, Ukraine \\ ${ }^{2}$ Faculty of Chemistry and Pharmacy, Sofia University, "St. Kliment Ohridski" 1 \\ blv. J. Bourchier, Sofia, 1164, Bulgaria \\ *E-mail: uliana.tarabara@gmail.com \\ Received 15 April 2019, revised May 5, 2019; accepted May 8, 2019
}

\begin{abstract}
The applicability of the novel cationic phosphonium dye TDV1 to monitor the complexation between DNA and pathologically aggregated proteins, amyloid fibrils, was tested using the optical spectroscopy and molecular docking techniques. TDV1 has been found to be highly emissive in buffer solution and is characterized by one well-defined fluorescence peak attributed to the dye monomers. The association of the dye with the double stranded DNA was followed by the enhancement of monomer fluorescence coupled with a bathochromic shift of the emission maximum. The addition of fibrillar lysozyme (LzF) to TDV1-DNA mixture led to the further enhancement of fluorescence intensity of the monomeric dye form coupled with a hypsochromic shift of the emission maximum and an appearance of a second long-wavelength peak. An assumption has been made that the fluorescence enhancement augmenting with increasing the protein concentration in the TDV1/DNA system is produced by the interaction of the free TDV1 monomers with lysozyme fibrils as well as by the LzF-induced conformational alterations of DNA. The long-wavelength peak emerging in the presence of LzF is presumably a consequence of the J-aggregate formation upon the TDV1 association with lysozyme fibrils. The molecular docking studies showed that TDV1 monomers are incorporated into the fibril grooves associating with $7 \beta$-strands in such a way that the dye long axis is parallel to the fibril axis. The most energetically favorable position of TDV1 is the S60-W62/G54-L56 groove in the lysozyme fibril core. In contrast, the TDV1 dimers seem to associate with the more hydrophilic side of the model $\beta$-sheet. Cumulatively, the results from the absorption and fluorescence measurements, together with the molecular docking analysis are consistent with the minor groove mode of the TDV1 binding to dsDNA. The electrostatic interactions seem to play a predominant role in the TDV1 complexation with the double stranded DNA, while the hydrophobic interactions and steric hindrances are supposed to be influential in the association of TDV1 with fibrillar lysozyme.
\end{abstract}

KEYWORDS: Phosphonium dye, fibrillar lysozyme, DNA, J-aggregates

Over the past decade the phenomenon of protein self-assembly into supramolecular aggregates, amyloid fibrils, attracts ever grooving interest due to its involvement in the molecular etiology of a number of debilitating disorders including Parkinson's, Alzheimer's, Huntington's, Creutzfeld-Jakob diseases, type II diabetes, etc. Although a consensus about the origin of such pathologies has been reached and is presented by the amyloid cascade hypothesis, the initial molecular events underlying fibril formation remain unclear [1]. The factors, such as the abnormal partial unfolding or folding of the proteins arising from the mutations, oxidative or heat stress or destabilization of the protein structure at the lipid-water interfaces are supposed to play essential role in amyloid growth $[2,3]$. Furthermore, a series of recent investigations provide evidence for the potential involvement of non-proteinaceous cofactors in the formation of amyloid deposits [4-7]. For instance, heparan sulfate, is reported to be linked with the amyloid disorders [4-5]. Likewise, the analysis of the brain tissues from victims of Alzheimer's disease revealed the presence of nucleic acids in the neurofibrillary tangles, intracellular inclusions composed of the tau protein and in the senile plaques consisting of the A $\beta$ peptides [7]. Despite an undeniable evidence for the presence of polyanions in amyloid deposits, the questions whether and how they affect fibrillogenesis, are still unclear. It has been demonstrated that RNA stimulates the prion protein conversion in vitro [8]. Kampers and co-workers have uncovered the ability RNA to provoke the aggregation of the microtubule-associated protein tau into Alzheimer-like paired helical filaments [9,10]. Moreover, the doublestranded DNA has been found to promote the fibrillation of $\alpha$-synuclein [11,12]. Remarkably, DNA is capable of strong associating with the mature fibrils of human muscle acylphosphatase, human lysozyme and hen egg white lysozyme $[13,14]$. There is also evidence that the cytotoxic action of soluble protein oligomers can be limited by the nucleic acids [15]. Despite great advances in the understanding the mechanisms behind the interactions of glycosaminoglycans and nucleic acids with fibrillar protein aggregates, little is known about the molecular scale details of this process. However, several studies have demonstrated that electrostatic interactions prevail in the polyelectrolyteamyloid fibril complexes $[13,14]$. A variety of powerful techniques, including an agarose gel based assay, circular dichroism, fluorescence and absorption spectroscopy, small-angle x-ray scattering, electron microscopy are currently used to monitor the DNA binding to amyloid fibrils. The complex nature of the interactions between the amyloid fibrils and polyanions like nucleic acids requires the development of sophisticated, although simple approaches, one of which involves the application of the extrinsic fluorescent dyes.

Among a variety of fluorescent compounds currently used in the DNA and amyloid fibrils studies an important place belongs to the dyes of cyanine family [16-20]. To exemplify, the oxazole yellow homodimer, which has 
previously been employed mainly as a DNA-intercalating probe, appeared to be suitable for in vitro amyloid sensing [16]. The ability to detect the protein fibrillar aggregates and to stain the double stranded DNA has been also shown for the mono-, tri-, penta- and heptamethine cyanine dye [17-20], styryl cyanine dyes [21,22], merocyanines [23], to name only a few. An extensive application of cyanines in the studies of amyloid fibrils and DNA is dictated by their favorable spectral properties, such as, particularly, high extinction coefficients, intensive absorption in a wide spectral region, from UV to NIR, high fluorescence intensity and quantum yield increase upon the dye binding to nucleic acids or proteins, etc. Another interesting property of the cyanines is their ability to form the selfassociates stabilized by the van-der Waals, H-bonding, electrostatic, steric, hydrophobic and stacking interactions [24,25]. Dictated by the geometry of the molecules within the aggregate, both the H-and J-aggregates have been observed. The aggregate type depends on the spatial arrangement of the transition dipoles of individual dye molecules and can be easily identified by the spectroscopic means [26]. Kasha has long proposed that the interaction between the transition dipoles of tightly packed molecules generates a splitting of the excited states into exciton levels [26]. For the J-aggregates, the lower exciton is allowed, thus resulting in a bathochromically shifted absorption, whereas for the card-pack H-arrangements only the upper state transition is allowed, giving rise to the hypsochromic shift of the absorption spectra. Importantly, DNA and amyloid proteins have been shown to have a significant impact on the aggregation properties of cyanines [19,27,28]. The remarkable ability of cyanines to interact both with nucleic acids and fibrillar protein assemblies with accompanying changes of the dye spectral properties gives the impetus for their use as effective reporters in tracing the DNA interaction with amyloid fibrils.

In view of this, the aim of the present study was the investigation of the ability of the novel phosphonium cyanine dye TDV1 to monitor the DNA-amyloid protein interactions.

\section{EXPERIMENTAL SECTION}

Materials

Hen egg white lysozyme, calf thymus DNA were from Sigma (Sigma, St. Louis, MO, USA). The phosphonium dye TDV1 was provided by Professor Todor Deligeorgiev, University of Sofia, Bulgaria. All other materials and solvents were commercial products of analytical grade and were used without further purification.

\section{Preparation of working solutions}

The stock solution of TDV1 was prepared by dissolving the dye in $5 \mathrm{mM}$ sodium phosphate buffer (pH 7.4). The concentration of TDV1 was determined spectrophotometrically, using the extinction coefficient $\varepsilon_{480}=2.1 \times 10^{5} \mathrm{M}^{-1} \mathrm{~cm}^{-1}$ The stock solution of calf thymus DNA was prepared in $10 \mathrm{mM}$ Tris-HCl, $0.5 \mathrm{mM}$ EDTA buffer ( $\mathrm{pH} \mathrm{7.4)} \mathrm{at} \mathrm{room} \mathrm{temperature} \mathrm{with} \mathrm{occasional} \mathrm{stirring} \mathrm{to} \mathrm{ensure} \mathrm{the} \mathrm{formation} \mathrm{of} \mathrm{a} \mathrm{homogenous} \mathrm{solution.} \mathrm{The}$ concentration of the DNA was determined spectrophotometrically using the extinction coefficient $\varepsilon_{260}=6.6 \times 10^{3} \mathrm{M}^{-1} \mathrm{~cm}^{-1}$. The lysozyme amyloid fibrils (Fig.1) were grown by the incubation of the protein solution $(10 \mathrm{mg} / \mathrm{ml})$ in $10 \mathrm{mM}$ glycine buffer $(\mathrm{pH} 2)$ at $60{ }^{\circ} \mathrm{C}$ for 14 days. The working solution of fibrillar lysozyme was prepared in $5 \mathrm{mM}$ Na-phosphate buffer ( $\mathrm{pH}$ 7.4). Fibril formation was assessed by the transmission electron microscopy. A $10 \mu \mathrm{l}$ drop of the protein solution was applied to a carbon-coated grid and blotted after $1 \mathrm{~min}$. A $10 \mu \mathrm{l}$ drop of $1.5 \%(\mathrm{w} / \mathrm{v})$ phosphotungstic acid solution was placed on the grid, blotted after $30 \mathrm{~s}$, and then washed 2 times by deionized water and air dried. The resulting grids were viewed by the EM-125 electron microscope (Selmi, Ukraine).

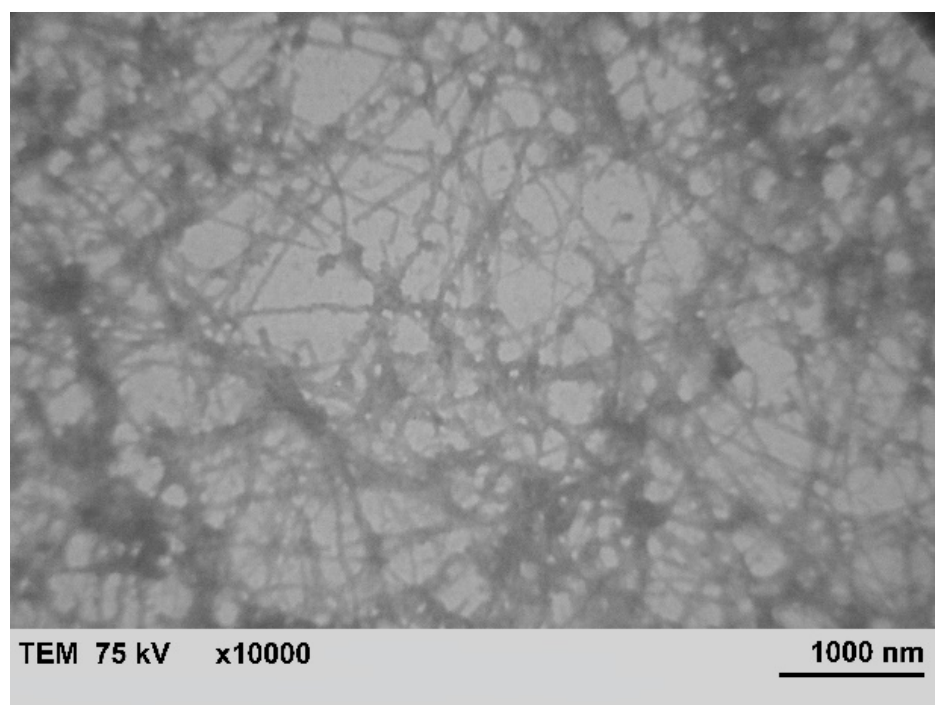

Fig. 1. Transmission electron microscopy image of lysozyme amyloid fibrils. Scale bar is $1000 \mathrm{~nm}$. 


\section{Spectroscopic measurements}

The absorption spectra of TDV1 were recorded with the spectrophotometer Shimadzu UV-2600 (Japan) at $25{ }^{\circ} \mathrm{C}$. The steady-state fluorescence spectra were recorded with RF6000 spectrofluorimeter (Shimadzu, Japan). The fluorescence measurements were performed at $20^{\circ} \mathrm{C}$ using $10 \mathrm{~mm}$ pathlength quartz cuvettes. The fluorescence spectra of cyanine dyes were recorded in the range of 500 to $750 \mathrm{~nm}$ with the excitation wavelength $480 \mathrm{~nm}$.

\section{Molecular docking study}

The molecular docking was performed to identify the possible sites for the TDV1 binding to lysozyme fibrils and to elucidate the nature of the interactions between the dye and fibrillar protein aggregates. The crystal structure of hen egg white lysozyme (PDB ID: 3A8Z) was taken from the Protein Data Bank. The $\beta$-structured core of the lysozyme fibril was built from the K-peptide, GILQINSRW (the residues 54-62 of the wild type protein), using the CreateFibril tool as described previously [29] The structure of TDV1 was built and optimized in Avogadro [30]. The docking models of the dye dimers and the complexes between the dye monomer (or dimer) and fibrillar lysozyme were obtained using the PatchDock algorithm, that is a user-friendly tool for calculation of the optimal structures of the protein-drug and protein-protein complexes. The online-available program searches the transformations of the two interacting molecules (assuming the proteins to be rigid bodies), revealing the maximized surface shape complementarity and minimized number of steric clashes. The top 10 of the obtained conformations were then refined by the FireDock algorithm, that calculates the optimal rearrangement of the side chains in the protein-ligand complex by the Monte Carlo minimization of the binding score function that is essentially determined by the energy of ligand-protein van der Waals interactions and the desolvation free energy.

An interacti examined phosphonium dye TDV1 and the double stranded DNA. The program performs docking using the spherical polar Fourier correlations with the inputs of ligand and receptor in PDB format. The structure of the B-DNA dodecamer d(CGCGAATTCGCG) ${ }_{2}$ (PDB ID: 1BNA) was downloaded from the Protein Data Bank (http://www.rcsb.org./pdb). The parameters used for the molecular docking include: FFT mode - 3D, correlation type shape only, grid dimension -0.6 , ligand range -180 , receptor range -180 , distance range -40 , and twist range -360 . The docked complexes were visualized by the Visual Molecular Dynamics (VMD) software.

\section{RESULTS AND DISCUSSION}

A widespread approach to monitoring the interactions of small ligands (dyes, drugs, etc.) with biological macromolecules is based on the use of UV-visible absorption spectroscopy. The magnitude of the changes in absorption intensity and other characteristics of the spectral band are usually correlated with the strength of interaction. Therefore, at the first step of study, to assess the sensitivity of the TDV1 to DNA-amyloid protein interactions, the absorption spectroscopy technique was utilized. As shown in Fig. 2, the absorption spectrum of TDV in buffer solution is characterized by one well-defined peak at $\sim 470 \mathrm{~nm}$.

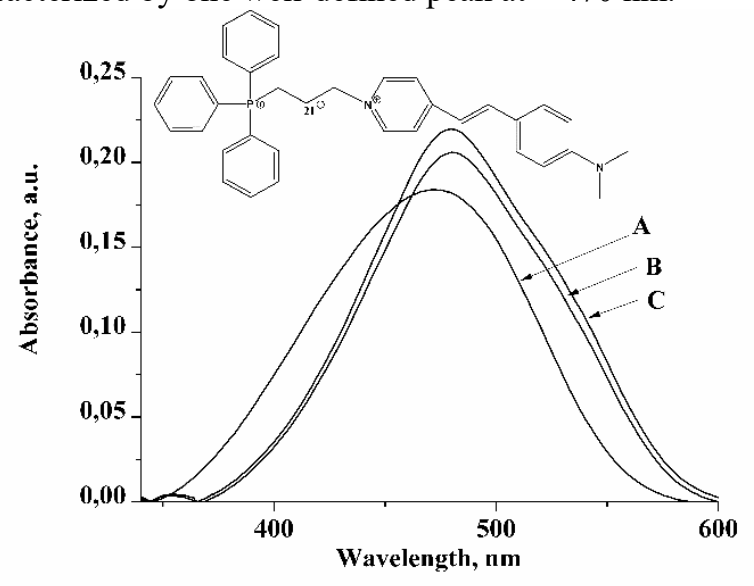

Fig. 2. Absorption spectra of TDV1 in buffer solution (A), in the presence of double stranded DNA (B) and in the combined DNA/fibrillar lysozyme system (C). TDV1 concentration was $11.8 \mu \mathrm{M}$. DNA concentration was $34 \mu \mathrm{M}$. Fibrillar lysozyme concentration was $0.7 \mu \mathrm{M}$. Shown in the inset is the structural formula of TDV1.

In the presence of double stranded DNA significant changes in the dye absorption spectra have been observed pointing to the strong association of TDV1 with the nucleic acid. The addition of DNA was accompanied by a small hyperchromism, $\sim 10 \mathrm{~nm}$ bathochromic shift of the absorption maximum coupled with a broadening of the absorption spectra due to appearance of a red-shifted shoulder at $540 \mathrm{~nm}$. A detailed analysis of the available literature on the dyenucleic acid interactions indicates that hyperchromism is a spectral feature reflecting the non-covalent interactions, particularly the electrostatic and minor groove binding motifs [22,31]. More interesting is the fact of broadening of the absorption spectrum, which can be attributed to the dye aggregation on the DNA template [27]. Generally, the cyanine dyes interact with the DNA minor grooves forming the plane-to-plane $\mathrm{H}$ dimers that can be identified easily through the appearance of a new absorption band hypsochromically shifted with respect to the monomer band $[20,32,33]$. However, for some cyanine dyes the end-to-end aggregation in a minor groove of DNA was observed resulting in the emergence of a new bathochromically shifted absorption band $[28,34,35]$. It should be noted, that the H-aggregates in the weak 
coupling regime possess an absorption band red-shifted relative to the monomeric band [36,37]. The existence of $\mathrm{H}-$ aggregates in the weak excitonic coupling regime was firstly proposed by Spano, who described the absorption and emission spectra of the linear $\mathrm{H}$ - and J-aggregates with the nearest-neighbor-only coupling $\left(J_{0}\right)$ as a function of the coupling strength [37]. Accordingly, a question arises, whether the aggregates formed on the DNA template are weakly coupled because of the plane-to-plane or end-to-end molecular arrangements? Taken into account that the width of the minor groove does not exceed $1.2 \mathrm{~nm}$, and the TDV1 is a relatively large dye (its length, width and height are $2.26 \mathrm{~nm}$, $0.99 \mathrm{~nm}$ and $0.99 \mathrm{~nm}$, respectively), the aggregation of the dye into the face-to-face molecular assemblies (even weakly coupled H-dimers) is blocked by the walls of the minor groove. Therefore, the observed red-shifted shoulder presumably corresponds to the dye head-to-tail dimers formed in the DNA minor groove. The addition of fibrillar lysozyme to the dye-DNA system has been accompanied by a slight increase of the monomer absorption along with a small broadening of the absorption spectrum. However, the observed changes in the absorption spectra in the presence of aggregated protein are too weak to give any realistic explanation since they can be attributed to the dye-LzF interactions as well as to the influence of lysozyme fibrils on the DNA structure.

In view of this, at the next step of the study, to assess the sensitivity of TDV1 to the DNA - amyloid protein interactions, the fluorescence spectra of the dye were recorded in the buffer solution, in the presence of double stranded DNA (Fig. 3) and in the combined dsDNA/LzF systems (Fig. 4). TDV1 appeared to be highly emissive in buffer solution (Fig. 3a). The DNA addition resulted in a significant increase of the fluorescence intensity coupled with a red shift of the emission maximum up to $9 \mathrm{~nm}$ (Fig. 3a). The observed fluorescence enhancement is most likely to arise from the rigidification of the fluorophore. Importantly, the absorption spectroscopy data point to the J-dimerization of the cyanine dyes on the DNA template. The end-to-end aggregates are commonly highly fluorescent. However, as can be seen from the TDV1 fluorescence spectra in the presence of DNA, only the fluorescence of monomers takes place. The above discrepancy between the absorption and fluorescent data is most likely to result from the different phosphateto-dye ratios (P/D). The absorption and fluorescence spectra were measured at the low (ca. 2.8) and high (ca. 134) P/D ratios, respectively. Generally, when the dye is in excess, cyanines tend to self-associate on the DNA template with the formation of the dye dimers in the minor groove, a tendency well described, in particular, for thiazole orange, Cyan 2 and Hoechst 33258 [34,38]. Further increase of the DNA concentration led to the binding of these dyes predominantly in the monomeric form. It should be noted that similar behavior was observed for acridine orange in the presence of the double stranded DNA [39]. At the high dye/DNA ratios, when the dye is in excess, its dimers bind electrostatically to the phosphate groups, whereas under the conditions of DNA excess strong intercalation is observed [39]. Due to the extended structure of the phosphonium dye under study, the exclusively intercalative binding mode for the TDV1 monomers seems unrealistic. However, the possibility of the "half intercalation" mode of the dye-DNA complexation cannot be ruled out [40]. In this case, the heterocycle with a high basicity accomodates in a more nucleophilic groove whereas heterocycle with a low basicity intercalates into a more electrophilic inter-base space [40].

a

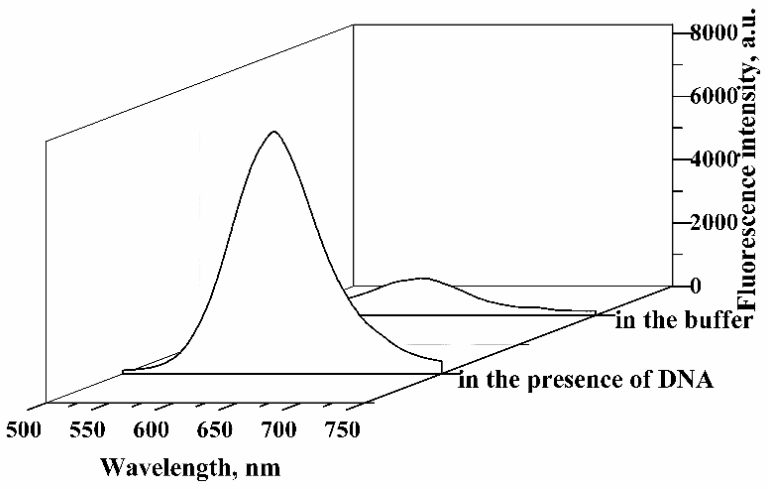

b

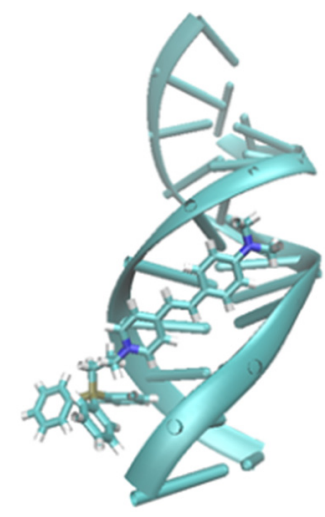

Fig. 3. Fluorescence spectra of TDV1 in buffer solution and in the presence of DNA. TDV1 concentration was $0.32 \mu \mathrm{M}$. DNA concentration was $42.8 \mu \mathrm{M}$ (a). Schematic representation of the energetically most favourable dye complex with the double stranded DNA (b). A NewCartoon drawing method (VMD) is employed to represent the DNA structure, and TDV1 is depicted by Bonds:

In an attempt to ascertain the mode of the dye-DNA binding, the molecular docking studies were performed. A double-stranded DNA dodecamer [d(CGCGAATTCGCG)2, PDB ID 1BNA] and TDV1 were taken as the input structures. Generally, to predict the best orientation of the ligand molecule within the double stranded DNA helix, the ligands are made flexible to attain different conformations. Therefore, in our docking studies the DNA structure was kept rigid, while the structure of TDV1 was made flexible to provide an energetically favorable docked pose. The molecular docking studies showed that TDV interacts with the minor groove of DNA (Fig. 3b).

The addition of fibrillar lysozyme to the TDV1-DNA mixture led to the 1.3-fold enhancement of the fluorescence intensity of the monomeric dye form coupled with a blue shift of the emission maximum up to $6 \mathrm{~nm}$ (Fig. 4a). In addition, a second well-defined peak at $703 \mathrm{~nm}$ was appeared. The enhancement of TDV1 fluorescence intensity at 
$618 \mathrm{~nm}$ can be interpreted in terms of the interaction of the free dye monomers with lysozyme fibrils as has been previously observed for the monomethine and trimethine cyanines [18]. However, we cannot rule out that the fluorescence intensity increase is caused by the LzF-induced alterations in the DNA structural state [13, 14]. The observed long-wavelength peak augmenting with the fibrillar lysozyme concentration presumably reflects the Jaggregate formation upon the TDV1 association with fibrils in the presence of DNA. Remarkably, the ability of rhodamine 6G to aggregate on the amyloid fibril template was reported by Hanczyc et al. [41], who demonstrated that the structural differences between the lysozyme and insulin amyloid fibrils promote the formation of the J-type and Htype molecular arrangements of the dye, respectively. The enhanced aggregation of the cyanine dye 7514 in the presence of fibrils was reported also by Volkova et al. [42] who ascribed the band shifted to the long-wavelength region relative to the monomer band to the formation of the J-aggregates. Presumably, the hydrophobic, electrostatic, and van der Waals interactions between the dye and the fibrillar proteins promote the formation of the dye J-aggregates. Notably, typical fibril binding sites for the small organic molecules are represented by the long surface grooves running parallel to the fibril axis, which may induce the end-by-end stacking of the fibril-bound TDV1 molecules, followed by the dye dimerization [43]. The simple docking studies were performed to assess the potential binding sites for TDV1 within the fibril core. As can be seen in Fig. 4 (panels "b" and "c"), the binding sites for TDV1 are represented by grooves formed by the polar and nonpolar amino acid residues. It appeared that TDV1 monomers are incorporated to the fibril grooves similarly to the classical amyloid marker Thioflavin T [44], associating with seven $\beta$-strands in such a way that the dye long axis is parallel to the fibril axis (Fig. 4b). The most energetically favorable positioning of TDV1 is provided by the groove S60-W62/G54-L56 of the lysozyme fibril core. In turn, TDV1 dimers seem to associate with a more hydrophilic surface of the lysozyme fibrils that is sterically more accessible for the dyes than the dry "steric zipper" interface [45]. Presumably, the dye-fibril hydrophobic interactions and steric hindrances have the predominant influence on the association of TDV1 with fibrillar lysozyme.

a

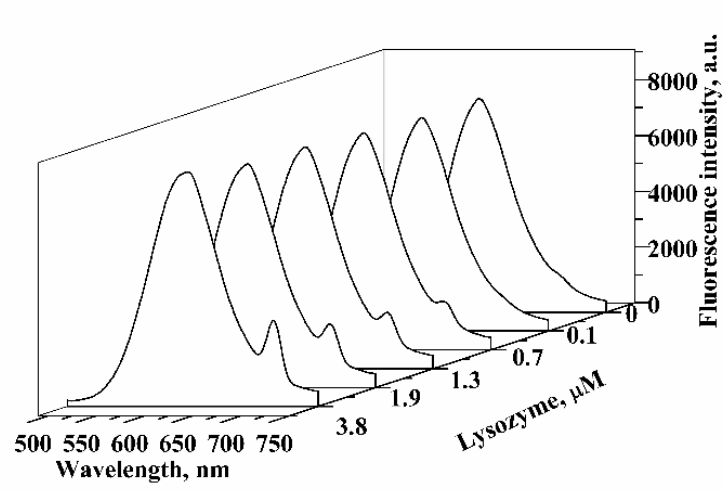

$\mathrm{b}$

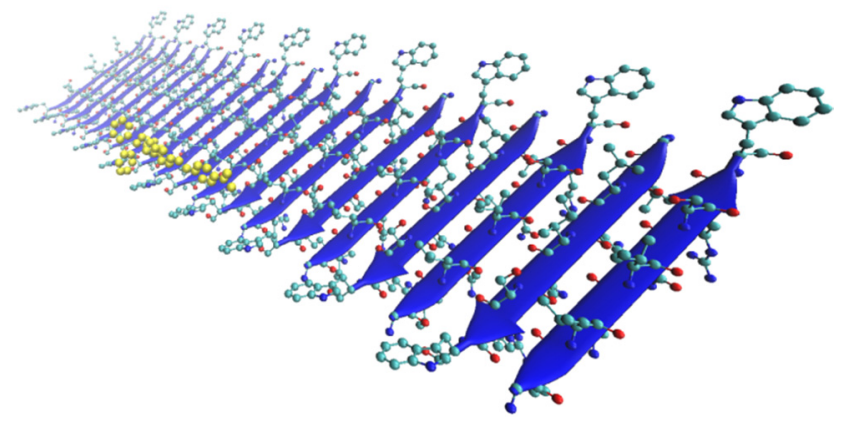

c

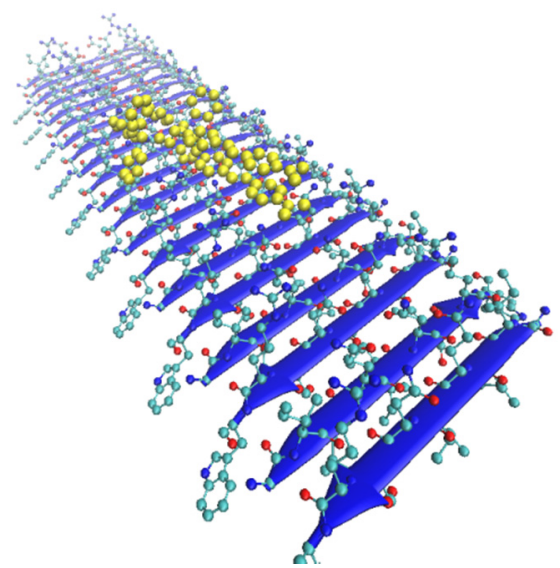

d

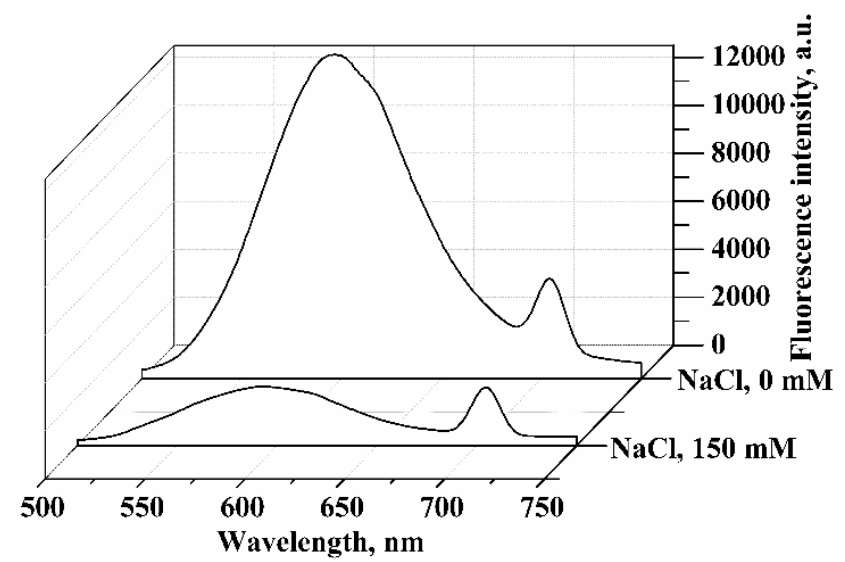

Fig. 4. Fluorescence spectra of TDV1 in buffer solution and in the presence of DNA. TDV1 concentration was $0.32 \mu \mathrm{M}$. DNA concentration was $42.8 \mu \mathrm{M}$. The most energetically favorable TDV1 monomer (b) and dimer (c) complexes with the fibrillar lysozyme, obtained using the molecular docking. Ligand and protein are represented via VDW and New Cartoon/CPK methods, respectively. Panel (d) represents the effect of sodium chloride on the fluorescence spectra of TDV1 in the combined DNA/LzF system. TDV1, DNA and LzF concentrations were $0.3 \mu \mathrm{M}, 42 \mu \mathrm{M}$ and $3.7 \mu \mathrm{M}$, respectively. 
It is crucial to note that the binding of free TDV1 monomers to lysozyme fibrils is not the only reason for the described above enhancement of the fluorescence intensity augmenting with increasing the protein concentration in the TDV1/DNA system (Fig. 4a). Probably, the observed fluorescence increase is produced by the LzF-induced conformational changes of the DNA molecule. Recent studies indicate that the nucleic acid binding to the lysozyme fibrils is nonspecific in nature and occurs presumably through electrostatic interactions [13,14]. The hydrophobicity negatively affects the strength of interactions between the oppositely charged DNA and fibrils since the stronger binding with the negatively charged nucleic acids is peculiar to the native lysozyme in comparison with the fibrillar Lz possessing the exposed hydrophobic regions [13]. The circular dichroism measurements indicate that both the native and fibrillar lysozyme can cause a deformation of the DNA helical structure [14]. Moreovere, the hydration pattern near the phosphate groups and ribose rings of DNA helix has been affected by proteins [14]. In view of the above, it is highly probable that fibrillar lysozyme affects the DNA structure in such a manner that the DNA minor grooves (putative TDV1 binding sites) become more accessible to the free dye molecules. An additional argument in favor of our hypothesis that TDV1 fluorescence enhancement at $618 \mathrm{~nm}$ to is largely determined by the LzF-induced conformational alterations of the DNA rather than by the interaction of the dye monomers with fibrils, comes from the ionic strength effect studies (Fig. 4d). The addition of $150 \mathrm{mM}$ sodium chloride to the TDV1/DNA/LzF mixture resulted in $\sim 6$-fold decrease in the monomer fluorescence intensity and 2-fold fluorescence reduction of the dimeric dye form at $703 \mathrm{~nm}$. Owing to the cationic nature of TDV1 and the negative polyphosphate skeleton of DNA, the electrostatic interactions seem to play a predominant role in the dye-nucleic acid complexation. It is generally known that in the presence of DNA, $\mathrm{Na}^{+}$ions partly neutralize the negative charges of the DNA phosphate backbone. As a result, the electrostatic attraction between the small molecules and DNA surface is weakened leading to the release of the TDV1 from the DNA minor grooves and concomitant decrease in the monomer fluorescence intensity. The 2-fold fluorescence reduction of the dimeric dye form at $703 \mathrm{~nm}$ is probably associated with the formation of atmosphere of $\mathrm{Cl}^{-}$counter-ions around the dye molecules, disrupting in such a way the cyanine dimers by sterical blocking of the endto-end contacts [46].

\section{CONCLUSIONS}

To summarize, the present study was focused on the investigation of the ability of the novel phosphonium cyanine dye TDV1 to monitor the DNA-amyloid protein interactions. The analysis of the fluorescence spectra of TDV1 in the presence of DNA and in the combined DNA/fibrillar lysozyme systems provides evidence for the binding of TDV1 monomers to the DNA minor groove and the association of the dye dimers with the hydrophilic surface of the lysozyme fibril core. The electrostatic interactions seem to be prevalent in the TDV1 complexation with the double stranded DNA. At the same time, the dye-fibril hydrophobic interactions and steric hindrances are supposed to dominate in the TDV1 binding to fibrillar lysozyme. The results obtained suggest that the novel phosphonium dye TDV1 may prove of value in elucidating the mechanisms of DNA interactions with pathogenic protein aggregates associated with the amyloid diseases.

\section{ACKNOWLEDGEMENTS}

This work was supported by the Ministry of Education and Science of Ukraine (the Young Scientist project № 0117 U004966 "Nano- and microsized liophylic and liophylized self-associated systems: application in modern technologies and biomedicine") and by the President's of Ukraine grant No 0118U002284 from the State Fund for Fundamental Research of Ukraine "Development of novel anti-amyloid strategies by high-throughput screening of inhibitors of pathological protein aggregation".

\section{ORCID IDs}

Olga Zhytniakivska@https://orcid.org/0000-0001-9554-0090, Uliana Tarabara $@$ https://orcid.org/0000-0002-7677-0779,

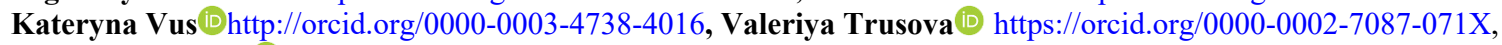
Galyna Gorbenko@http://orcid.org/0000-0002-0954-5053

\section{REFERENCES}

[1]. E. Karran, M. Mercken and B. Strooper, Nature Reviews Drug Discovery, 10, 698-712 (2011), doi: 10.1038/nrd3505.

[2]. J. Adamcik and R. Mezzenga, Macromolecules, 45, 1137-1150 (2012), doi: 10.1021/ma202157h.

[3]. C.M. Dobson, Cold Spring Harb. Perspect. Biol. 9, 1-14 (2017), doi: 10.1101/cshperspect.a023648.

[4]. J. Diaz-Nido, F. Wandosell and J. Avila, Peptides. 23, 1323-1332 (2002), doi: 10.1016/S0196-9781(02)00068-2.

[5]. J. van Horssen, P. Wesseling, L.P. van den Heuvel, R.M. de Waal and M.M. Verbeek, Lancet. Neurol. 2(8), 482-492 (2003), doi: 10.1016/S1474-4422(03)00484-8.

[6]. J.B. Ancsin, Amyloid. 10, 67-79 (2003), doi: 10.3109/13506120309041728.

[7]. S.D. Ginsberg, J.E. Galvin, T.S Chiu, V.M. Lee, E. Masliah and J.Q. Trojanowski, Acta Neuropathol. 96(5), 487-494 (1998), doi: $10.1007 / \mathrm{s} 004010050$.

[8]. M.R. Deleault, R.W. Lucassen and S. Supattapone, Nature, 425, 717-720 (2003), doi: 10.1038/nature01979.

[9]. M. Hasegawa, R.A. Crowther, R. Gakes and M. Goedert, J. Biol. Chem. 272, 33118-33124 (1997), doi: $10.1074 / \mathrm{jbc} .272 .52 .33118$.

[10]. T. Kampers, P. Friedhoff, J. Biernat, E.M. Mandelkow and E. Mandelkow, FEBS Lett. 399(3), 344-349 (1996), doi: 10.1016/S0014-5793(96)01386-5. 
[11]. M.L. Hedge and K.S.J. Rao, Arch. Biochem. Biophys. 464(1), 57-69 (2007), doi: 10.1016/j.abb.2007.03.042.

[12]. D. Cherny, W. Hoyer, V. Subramaniam and T.M. Jovin, J. Mol. Biol. 344, 929-938 (2004), doi: 10.1016/j.jmb.2004.09.096.

[13]. M. Calamai, J.R. Kumita, J. Mifsud, C. Parrini, M. Ramazzotti, G. Ramponi, N. Taddei, F. Chiti and C. Dobson, Biochemistry. 45, 12806-12815 (2006), doi: 10.1021/bi0610653.

[14]. S. Ghosh, N.P. Pandey, S. Sen, D.R. Tripathy and S. Dasgupta, J. Photochem. Photobiol. B. 127, 52-60 (2013), doi: 10.1016/j.jphotobiol.2013.07.015.

[15]. J.D. Domizio, R. Thang, L.J. Stagg, M. Gagea, M. Zhuo, J.E. Ladbury and W. Cao, J. Biol. Chem. 287, 736-747 (2012), doi: $10.1074 /$ jbc.M111.238477.

[16]. D.L. Lindberg and E.K. Esbjorner, Biochem. Biophys. Res. Commun. 469, 313-318 (2016), doi: 10.1016/j.bbrc.2015.11.051.

[17]. V.B. Kovalska, M.Y. Losytskyy, O.I. Tolmachev, Y.L. Slominskii, G.M. Segers-Nolten, V. Subramaniam and S.M. Yarmoluk, J. Fluoresc. 22, 1441-1448 (2012), doi: 10.1007/s10895-012-1081-x.

[18]. K.D. Volkova, V.B. Kovalska, A.O. Balanda, R.J. Vermeij, V. Subramaniam, Y.L. Slominskii and S.M. Yarmoluk, J. Biochem. Biophys. Meth. 70, 727-733 (2007), doi: 10.1016/j.jbbm.2007.03.008.

[19]. K.Vus, U. Tarabara, A. Kurutos, O. Ryzhova, G. Gorbenko, V. Trusova, N. Gadjev and T. Deligeorgiev, Mol. Biosyst. 13, 970-980 (2017), doi: 10.1039/c7mb00185a.

[20]. A. Kurutos, O. Ryzhova, U. Tarabara, V. Trusova, G. Gorbenko, N. Gadjev and T. Deligeorgiev, J. Photochem. Photobiol. A. 328, 87-96 (2016), doi: 10.1016/j.jphotochem.2016.05.019.

[21]. Q. Li, J.-S. Lee, C. Ha, C. B. Park, G. Yang, W. B. Gan and Y.-T. Chang, Angew. Chem. Int. Ed. 43(46), 6331-6335 (2004), doi: $10.1002 /$ anie. 200461600 .

[22]. C.V. Kumar, R.S. Turner and E.H. Asuncion, J. Photochem. Photobiol. A. 74, 231-238 (1993), doi: 10.1016/10106030(93)80121-O.

[23]. J. Yan, J. Zhu, K. Zhou, J. Wang, H. Tan, Z. Xu, S. Chen, Y. Lu, M. Cui, L. Zhang, Chem. Comm. 53, 9910-9913 (2017), doi: 10.1039/C7CC05056A.

[24]. M.K. Johansson, H. Feedder, D. Dick, and R.M. Cook, J. Am. Chem. Soc. 124(24), 6950-6956 (2002), doi: 10.1021/ja025678o.

[25]. B. Birkan, D. Gulen and S. Ozcelic, J. Phys. Chem. 110, 10805-10813 (2006), doi: 10.1021/jp0573846.

[26]. M. Kasha, H.R. Rawls and M.A. El-Bayoumi, Pure. Appl. Chem. 100, 17287-17296 (1996).

[27]. K.S. Hannah and B.S. Armitage, Acc. Chem. Res. 37, 845-853 (2004), doi: 10.1021/ar030257c.

[28]. M. Wang, G. Silva and B. Armitage, J. Am. Chem. Soc. 122, 9977-9986 (2000), doi: 10.1021/ja002184n.

[29]. M.R. Smaoui, F. Poitevin, M. Delarue, P. Koehl, H. Orland, and J. Waldispühl, Biophys. J. 104(3), 683-693 (2013), doi: 10.1016/j.bpj.2012.12.037.

[30]. M.D. Hanwell, D.E. Curtis, D.C. Lonie, T. Vandermeerch, E. Zurek and G.R. Hutchison, J. Cheminform. 4, 17 (2012), doi: 10.1186/1758-2946-4-17.

[31]. T. Sarwar, S. Rehman, A.A. Husain, H.M. Ishqi and M. Tabish, Int. J. Biol. Macromol. 73. 9-16 (2015), doi: 10.1016/j.ijbiomac.2014.10.017.

[32]. J.L. Seifert, R.E. Connor, S.A. Kushon, M. Wang and B.A. Armitage, J. Am. Chem. Soc. 121, $2987-2995$ (1999), doi: $10.1021 / \mathrm{ja} 984279 \mathrm{j}$.

[33]. D.E. Wemmer, Annu. Rev. Biophys. Biomol. Struct. 29, 439-461 (2000), doi: 10.1146/annurev.biophys.29.1.439.

[34]. T.Yu. Ogul'chansky, M.Yu. Losytsky, V.B. Kovalska, S.S. Lukashov, V.M. Yashcuk and S.M. Yarmoluk, Spectrochim. Acta. A. Mol. Biomol. Spectrosc. 57, 2705-2715 (2001), doi: 10.1016/S1386-1425(01)00537-6.

[35]. G.Ya. Guralchuk, A.V. Sorokin, I.K. Katrunov, S.L. Yefimova, A.N. Lebedenko, Yu.V. Malyukin and S.M. Yarmoluk, J. Fluoresc. 17, 370-376 (2007), doi: 10.1007/s10895-007-0201-5.

[36]. H. von Berlepsch, C. Böttcher, A. Ouart, C. Burger, S. Dähne, S. Kirstein, J. Phys. Chem. B. 104(22), 5255-5262 (2000), doi: $10.1021 /$ jp000220z.

[37]. S. Spano, Acc. Chem. Res. 43(3), 429-439 (2010), doi: 10.1021/ar900233v.

[38]. T. Stokke and T. Steen, J. Histochem. Cytochem. 33(4), 333-338 (1985). doi: 10.1177/33.4.2579998.

[39]. J. Kapuscinski, Z. Darzynkiewicz and M.R. Melamed, Biochem. Pharm. 32(24), 3679-3694 (1983).

[40]. S.M. Yarmoluk, S.S. Lukashov, T.Yu. Ogul'chansky, M.Yu. Losytskyy and O.S. Kornyushyna, Biopolymers. 62, 219-227 (2001).

[41]. P. Hanczyc, L. Sznitko, C. Zhong and A. Heeger, ACS Photonics. 2(12), 1755-1762 (2015), doi: 10.1021/acsphotonics.5b00458.

[42]. K.D. Volkova, V.B. Kovalska, M.Y. Losytskyy, K.O. Fal, N.O. Derevyanko, Y.L. Slominskii, O.I. Tolmachov and S.M. Yarmoluk, J. Fluoresc. 21, 775-784 (2011), doi: 10.1007/s10895-010-0770-6.

[43]. M. Groenning, M. Norrman, J. Flink, M. Weert, J. Bukrinsky, G. Schluckebier and S. Frokjaer, J. Struct. Biol. 159(3), 483-497 (2007), doi: 10.1016/j.jsb.2007.06.004.

[44]. M.R.H. Krebs, E.H. C. Bromley and A.M. Donald, J. Struct. Biol. 149, 30-37 (2005), doi: 10.1016/j.jsb.2004.08.002.

[45]. K.Vus, V. Trusova, G. Gorbenko, R. Sood, E. Kirilova, G. Kirilov, I. Kalnina and P. Kinnunen, J. Fluoresc. 24, $493-504$ (2014), doi: 10.1007/s10895-013-1318-3.

[46]. F.A. Schaberle, V.A. Kuz'min, and I.E. Borissevitch, Biochim. Biophys. Acta. 1621, 183-191 (2003), doi: 10.1016/S03044165(03)00057-6.

\section{НОВИЙ ФОСФОНІЄВИЙ БАРВНИК ЯК ПОТЕНЦІЙНИЙ ФЛУОРЕСЦЕНТНИЙ ЗОНД ДЛЯ ДОСЛІДЖЕННЯ

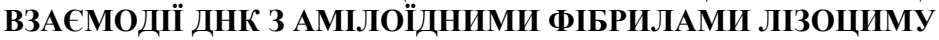 \\ О. Житняківська ${ }^{1}$, У. Тарабара $^{1}$, К. Вус ${ }^{1}$, В. Трусова ${ }^{1}$, Г. Горбенко ${ }^{1}$, Н. Гаджев ${ }^{2}$, Т. Делігеоргісв ${ }^{2}$ \\ ${ }^{1}$ Кафедра ядерної та медичної фізики, Харківський начіональний університет імені В.Н. Каразіна пл. Свободи 4, Харків, 61022, Украӥна \\ ${ }^{2}$ Факультет хімії і фармаиії, Софійський університет, Софія, 1164, Болгарія}

За допомогою методів оптичної спектроскопії і молекулярного докінгу проведена оцінка можливості використання нового катіонного фосфонієвого барвника TDV1 для дослідження комплексоутворення між ДНК і патогенними білковими агрегатами, амілоїдними фібрилами. Виявлено, що для мономерів TDV1 характерна висока інтенсивність флуоресценції у 
буферному розчині. При взаємодії барвника 3 подвійною спіраллю ДНК спостерігалось зростання інтенсивності флуоресценції мономерів та відбувався батохромний зсув максимуму флуоресценції. При додаванні фібрилярного лізоциму (LzF) до суміші TDV1-ДНК, поряд з подальшим підвищенням інтенсивності флуоресценції мономерної форми барвника i гіпсохромним зсувом максимуму випромінювання, спостерігалась поява додаткового, довгохвильового піку. Зроблено припущення, що зростання інтенсивності флуоресценції зі збільшенням концентрації білка в системі TDV1/ДНК зумовлене як взаємодією вільних мономерів TDV1 з фібрилами лізоциму, так і конформаційними змінами ДНК, викликаними фібрилами лізоциму. Поява довгохвильового піку, ймовірно, є результатом Ј-агрегації TDV1 у присутності фібрилярного білка. 3 використанням методу молекулярного докінгу показано, що мономери TDV1 зв'язуються 3 сімома ланцюгами борозенки фібрил лізоциму таким чином, що їх поздовжня вісь паралельна осі фібрили. Показано, що найбільш енергетично вигідним центром зв'язування є борозенка, сформована амінокислотними залишками S60-W62/G54-L56. В той же час, димери барвника утворюють стабільні комплекси з більш гідрофільною стороною модельного $\beta$-листа. Результати, отримані методами флуоресцентної, абсорбційної спектроскопії і молекулярного докінгу свідчать про взаємодію TDV1 3 малою борозенкою ДНК. Електростатичні взаємодії, вочевидь, $\epsilon$ домінуючими при комплексоутворенні TDV1 3 дволанцюговою ДНК, тоді як гідрофобні взаємодії та стеричні чинники є визначальними при асоціації барвника 3 фібрилярним лізоцимом.

КЛЮЧЕВЫЕ СЛОВА: Фосфонієвий барвник, фібрилярний лізоцим, ДНК, Ј-агрегати

\section{НОВЫЙ ФОСФОНИЕВЫЙ КРАСИТЕЛЬ КАК ПОТЕНЦИАЛЬНЫЙ ФЛУОРЕСЦЕНТНЫЙ ЗОНД ДЛЯ ИССЛЕДОВАНИЯ ВЗАИМОДЕЙСТВИЯ ДНК С АМИЛОИДНЫМИ ФИБРИЛЛАМИ ЛИЗОЦИМА

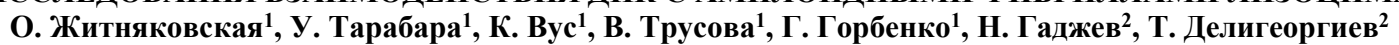 ${ }^{1}$ Кафедра ядерной и медицинской физики, Харьковский начиональный университет имени В.Н. Каразина пл. Свободыс 4, Харьков, 61022, Украина \\ ${ }^{2}$ Факультет химии и фармации, Софийский университет, София, 1164, Болгария}

$\mathrm{C}$ помощью методов оптической спектроскопии и молекулярного докинга проведена оценка возможности использования нового катионного фосфониевого красителя TDV1 для изучения комплексообразования между ДНК и патогенными белковыми агрегатами, амилоидными фибриллами. Обнаружено, что TDV1 обладает высокой интенсивностью флуоресценции мономеров в буферном растворе. Ассоциация красителя с двухцепочечной ДНК сопровождалась усилением флуоресценции мономеров в сочетании с батохромным сдвигом максимума испускания. Добавление фибриллярного лизоцима (LzF) к смеси TDV1-ДНК, наряду с дальнейшим увеличением интенсивности флуоресценции мономерной формы красителя и гипсохромным сдвигом максимума излучения мономеров, приводило также к появлению дополнительного, длинноволнового пика. Сделано предположение, что увеличение интенсивности флуоресценции с увеличением концентрации белка в системе TDV1/ДНК обусловлено как взаимодействием свободных мономеров TDV1 с фибриллами лизоцима, так и вызванными фибриллярным лизоцимом конформационными изменениями ДНК. Наблюдаемый длинноволновый пик, предположительно, является результатом образования Ј-агрегатов при ассоциации TDV1 с фибриллами лизоцима. С использованием метода молекулярного докинга показано, что мономеры TDV1 связываются с семью $\beta$-тяжами бороздки фибрилл таким образом, что их длинная ось параллельна оси фибрилл. Наиболее энергетически выгодным центром связывания TDV1 является бороздка S60-W62/G54-L56. В то же время, димеры TDV1, по-видимому, образуют стабильные комплексы с более гидрофильной поверхностью модельного $\beta$-листа. В совокупности, результаты, полученные методами флуоресцентной и абсорбционной спектроскопии, а также данные молекулярного докинга свидетельствуют о связывании TDV1 с малой бороздкой ДНК. Электростатические взаимодействия, по-видимому, являются преобладающими в связывании TDV1 с двухцепочечной ДНК, тогда как гидрофобные взаимодействия и стерические факторы определяют ассоциацию красителя с фибриллярным лизоцимом.

КЛЮЧЕВЫЕ СЛОВА: Фосфониевый краситель, фибриллярный лизоцим, ДНК, Ј-агрегаты. 